\title{
The Verbalization of Music in Fiction
}

\section{Introduction}

The tendency towards the integration of study units and development of interdisciplinary research in literature manifests itself in the fact that intercontextuality, interdiscursiveness, multimodality are becoming the leading principles of the conceptual and aesthetic phenomena analysis. This approach enables scientists to look into the invariant mechanisms of information functioning and general regularities of its production in the text. The text in this case is understood broadly as a cultural phenomenon, regardless of its material character, that is, it can be a literary, a musical, or a visual artwork.

Attempting intersemiotic research of the time-based forms of art, such as fiction or cinematography, it may be useful to start with the musical text as sample model, because many mechanisms of the production of conceptual and aesthetic information are more transparent there than in a verbal text. This is preconditioned, firstly, by the relative semiotic homogeneity of the musical text as a result of its material substrate being non-sign and, secondly, by the absolute evidence of such universal semiotic categories as creativity, syncretism and regularity which are "strong" for the musical text and will be discussed further. Thus, the processes of conceptual and aesthetic information production in music are more transparent are universal and, though less obviously, take place in fiction as well.

The musical text in this research is understood as a generalized model of classical pieces of music which is built on the basis of theoretical musicological works and analysis of musical verbalizations (musical episodes in fiction). The model is then compared with the literary works which are regarded as so-called musical prose - by Thomas Mann, 
Herman Hesse, Hans Henny Jahnn, Heimito von Doderer, Wolfgang Hildesheimer and other writers. The musical character of their works has been pointed out either by the authors themselves or their researchers.

The aim of the present study is to analyze the ways in which musical aesthetic information is transported into fiction, inducing such peculiarity of literary works as their "musicality".

The transposition of semantic and aesthetic information from music into fiction and vice versa presents considerable challenges because of the profound differences between the two semiotic systems - music and literature. Within Roman Jakobson's classification of the types of translation, this kind can be referred to as intersemiotic translation, that is interpretation of verbal signs by means of non-verbal sign systems (Jakobson 1978: 16-24), but in this research the verbal semiotic system is considered as a target component of the intersemiotic process, not as a source one.

\section{Typological Peculiarities of Music and Fiction Texts}

Different attempts at typological description of various forms of art, literature and music in particular, reveal fundamental differences on the lower levels (sign level of the natural language in fiction and pre-sign level in music), whereas many similar semiotic processes are witnessed on the level of the work of art as a whole.

The fact that the secondary sign system in fiction uses the natural language as the first level is the reason why there exist at least two sign levels in the literary text - first, the level of symbolic language signs and second, the level of aesthetic signs of a certain literary work or a certain author's corpus of works, or of an art movement. Musical works lack the first sign level similar to the sign system of natural language.

Although some musicologists consider onomatopoeia, intonation patterns of a question or exclamation, or slowing down before the end of the musical work to be iconic musical signs, these signs are sporadic and are not of systematic character. In our research we believe it to be more appropriate to look upon musical signs on the level of musical speech, not musical language. This will enable us to consider music theme or music intonation as aesthetic signs, the main criteria for distinguishing the musical sign being recurrence combined with variability and theme recognizability in the process of listening as it is these elements that should bear the formative function. 
The fundamental peculiarities of the inner structure of the texts belonging to different semiotic systems are also determined by the way universal semiotic categories are functioning in the text, such as discursive creativeness, syncretism and regularity. Universal semiotic categories mainly reflect the particular quality of text at an upper level of semiotic organization and while the upper semiotic levels are universal, material characteristics of sub-sign levels are specific.

In music the category of discursive creativeness is realized in its unlimited capacity to produce the units of the individual code and the existence of multidimensional links among them. The following production sequence is characteristic of musical creativity: discourse (of the music movement or composer's imagination) - the text of the music work - the language (the work's individual code or aesthetic signs).

In our opinion, this sequence of aesthetic information production is universal for all time-based literary texts, but in fiction, in contrast to music, its potential is limited by the presence of the first level - the natural language. As Yuri Lotman observes, the process of verbal text production is going in two directions - from the word sign towards the text and from the text towards the sign (Lotman 1981: 3-17). What is common for aesthetic information production in the process of artistic communication is the primary character of the discourse and the secondary character of aesthetic signs, which do not exist before the discourse, but appear as a result of an artistic communication event.

The category of syncretism has two aspects: the simultaneity of the signifiers and the interpenetration of signifiers and signified, that is the appliance of the material substance to transfer the information. The result can be seen in the existence of the immediate connection of the material and sense-bearing moments, the interdependence and convergence of different levels of the musical image. Hence that very integrity of the musical message which was mentioned by Thomas Mann's character in Doctor Faustus: "In der Tat sei sie (Musik) die geistigste aller Künste, was sich schon daran erweise, dass Form und Inhalt in ihr, wie in keiner anderen, ineinander verschlungen und schlechthin ein und dasselbe seien" (Mann 1975a: 85). In fiction syncretism is realized in the signification of the material qualities of linguistic signs on the phonetic, morphological, word-formation and syntactic levels - i.e. essential information is rendered through matter.

The high level of regularity of a musical text is explained by the predominance of the syntactic dimension of its semiotic system in comparison with the semantic orientation being dominant in fiction. 
Moreover, it is determined by the conditions of perception, the necessity to realize the mnemonic-oriented function.

The semantic dimension in music is "degenerated" (Orlov 1992: 462). As observed by Boris Gasparov, musical signs are not determined, but determining, they are primary in relation to denotation (Gasparov 1973: 33-44). The musical text aims at the sense, not the content, which explains the impossibility of exact nomination; attempts to convey the sense of the musical sign with exact denotations are unproductive. This point can be illustrated by the example from the text by Andrei Upit "Music", where the listeners' impressions from the same musical work are described and the denotations constructed by them are absolutely different.

The difference in the realization of semiotic categories of regularity and syncretism in fiction and music lies in the fact that while in music they form both upper and lower levels of the text, from separate sounds to the whole text, in fiction they are seen only on the relatively high levels. For instance, the rhythm in fiction shows itself on the level of the sentence and above.

Another important peculiarity of music as a form of art is its processual character, its ability to convey a person's inner life in its development and fluidity. According to Aleksei Losev, "It is the process of generation which is the cornerstone of music [...]. It is impossible to explain that particularly exciting character which distinguishes a work of music" (Losev 1990: 73). The continuity of development and the processuality in music corresponds to the continuity of the emotional state of the person that is actually the main subject of the iconic representation. One of the most "musical" writers, Aldous Huxley, claims that music says several things simultaneously in the way they merge (Huxley 2004: 8).

\section{The Application of Methods of Music Composition in Fiction}

The intensification of the syntactic orientation of semiosis at the expense of the semantic dimension leads to the complication and higher regularity of the text, the recurrence of elements and their redundancy, the predominance of coordination over subordination, overt diagonal connections (partial similarity between distant elements), the formation of the work according to a definite scheme (analogy building, compositional symmetry, partial text modelling) including musical form - sonata allegro, fugue, variations, rondo, etc. 
The extrapolation of musical form onto fiction can be found more often than one might have supposed. There have been many attempts of deliberate application of musical form in literary works; this is reflected either in the title (Sieben Variationen über ein Thema von Johann Peter Hebel Heimito von Doderer, Death Fugue Paul Celan, Symphonies Andrei Bely) or in the author's remarks, for example, Herman Hesse dwelling upon Der Steppenwolf, Hans Henny Jahnn upon his trilogy Fluß ohne Ufer or Thomas Mann upon Tonio Kröger. But more frequently musical form in fiction appears unconsciously. For example, the author of the academic study of the sonata form in Pushkin's poetry, Samuil Feinberg writes that the sonata form "might have entered Pushkin's poetry only as a result of intuition of a genius" (Feinberg 1973: 282).

There exist a number of music and literary studies both general (Petri, Klein), and devoted to a particular writer's creative work, whose authors trace the parallels between the composition of literary and musical works. Most frequently, similarity can be seen in poetry (Etkind, Feinberg) and in Thomas Mann's prose (Jung, Petri) to the sonata form, in Dostoevsky's (Alshvang), Thomas Mann's (Jung) and Jeane-Paul's (Dürr) creations with the symphony, in some of Thomas Mann's works (Jung) with the ouverture and fugue, in H. H. Jahnn's prose (Emrich) with the adagio, etc.

There are also cases in which it is difficult to identify the exact type of musical form in fiction in spite of the general similarity with the principles of musical composition. This concerns H.H. Jahnn's trilogy Fluß ohne Ufer (Boetlus), Herman Hesse's novel Der Steppenwolf (Dürr), some works of Dostoevsky (Asrieva), the eleventh chapter of Joyce's novel Ulysses (Petri), etc.

Suzanne Langer points out that musical form reflects dynamic models of inner experience, hence the significance of the principle of universality in music. Claude Levi-Strauss stresses the fundamental role of music along with myth as a projection of fundamental laws, reflecting the unconscious structure of the mind, onto the level of consciousness (ДевиСтросс 1972: 71). While musical works are influenced by the abstract semantics of musical form, one must note that this creates a problematic situation in the addressee's mind, and its resolution, that is awareness, is possible only because of the tension between this situation and similar situations the recipient has already experienced. More than that, the perception of musical texts as well as literary works built in accordance with musical forms presupposes the addressee's creative activity in meaning perception. Semantic ambiguity in this case is compensated by the explicit pragmatic dimension of the text. 
Following Viktor Bobrovski, musical form is studied in this paper in two aspects: as a principle and as a fact (Bobrovski 1975:3-9). Musical form as a principle is a relatively fixed model of cognitive organization, while its concrete representation is a collection of musical works. In relation to our paper, in fiction musical form as a principle results in common analogies with the corresponding musical realization, which might have been non-deliberate and thus reflecting some of the universal laws of literary communication. The musical form as a fact is seen as a writer's striving for a detailed reconstruction of the corresponding musical form.

Our research shows that musical form in fiction is quite often employed as a principle, and the most frequent such principles are the ones of sonata, fugue and variations. This article is too short to give a detailed analysis of literary works built on musical form. So, we will limit ourselves to some comments on the semantics of the best-known types of musical form in fiction.

Among the types of musical form, sonata-allegro is of a particular interest because of its recurrence (sonata devices are typical of antique rhetoric and found in many poetic and prose works), as well as its universal character (the sonata principle has one-to-one correspondence with Hegel law of contradiction). The peculiarities of fiction in the form of sonata are ternary form; parallel plot or formal elements in the first and third reprise parts; theme development as a result of opposed themes confrontation followed by convergence that is expressed by key words and leading-motives, etc. The deep semantics of a sonata form can be interpreted as the internalization of outer contradiction and its partial resolution or psychological compensation, as in Thomas Mann's novel Tonio Kröger or Chekhov's The Black Monk.

The form of a fugue is also widespread in fiction and among its characteristics we'd like to mention the polyphonism of the plot, the analytic structure realized in the fractioning of the theme elements, the counterpoint, which is realized in combination of several temporal or other planes in a short piece of text. The syntactic organization of the fugue-like text is characterized by the predominance of a horizontal type over a vertical one. It can be illustrated by the novels of Franz Fühmann and Wald Hildesheimer's Legende vom großen Bett.

The last musical form we would like to distinguish here is the variation, marked by invariant propositional functions, through-composed plot details, recurrent semantic attributes connecting different variations, tendency towards synonymy, polysemy and homonymy, analogous text building. Thus the integral content of the literary work is realized in the elements' varying recurrence on different text levels. Examples can 
be found in Sieben Variationen über ein Thema von Johann Peter Hebbel by Heimito von Doderer and the philosophical parable by Yurii Mamleev Sleeping in the forest.

The results of the comparison of literary and musical texts enables us to transfer some musicological terms and categories to text linguistics, for example the fugue presentation, sonata principles, variability, etc. On the other hand, many linguistic terms, such as syntax, actual division, distribution, are widely used while analyzing the musical text. It thus seems possible to work out a model language comprising a set of universal notions, which might be used to describe texts belonging to processual forms of art, though we should note that some musical terms (counterpoint, polyphony, etc.) used in philology have a different meaning.

\section{The Transposition of Musical Information into Fiction}

To study the ways in which musical semantics can be verbalized, we have analyzed some musical episodes in fiction, which we call musical verbalizations, where the author explicates the impressions of people listening to music or performing music. The material for the analysis was taken from the novels by English and German writers in whose works classical music plays a very important role (Thomas Mann, Aldous Huxley and others).

While classifying musical verbalizations in fiction we take into account the following criteria:

1. Is the performed music real or fictional? For example, descriptions of Adrian Leverkyn's fictional works in Thomas Mann's Doctor Faustus.

2. Is the music described from the listener's or performer/composer's point of view?

3. To what extent is the processual aspect realized?

Taking into account the extent to which the processual aspect of the musical text is considered in the process of verbalization, musical verbalizations are divided into retelling and description. The retelling transfers the impressions from a musical work gained in the process of its development at a definite moment, while the description is musical and critical research and appeals to the reader's reason. The first type includes musical episodes connected with Hanno Buddenbrook from Thomas Mann's Buddenbrooks, and the second one includes descriptions of Adrian Leverkyn's fictional works in Thomas Mann's Doctor Faustus. 
Retellings are found when the author describes the characters who are professional musicians, employ musical terms and mark the moments of their musical development. One example can be an episode of Hanno's improvisation scene in Thomas Mann's Doctor Faustus. The author manages to show the evolution of the musical work written in the sonata allegro form. The development and opposition of the two themes, which finish with the defeat of the main one, fill the plot-composite and have a symbolic function on the level of macrotext, predicting Hanno's death and the Buddenbrooks' demise.

Another example of the retelling can be found in Amsterdam, where the successive development of the symphony which exists in the composer's imagination is shown:

The ancient stone steps had been climbed, the wisps of sound had melted away like mist, his new melody, darkly scored in its first lonely manifestation for a muted trombone, had gathered around itself rich orchestral textures of sinuous harmony, then dissonance and whirling variations that spun away into space, never to reappear, and had now drawn itself up in a process of consolidation, like an explosion seen in reverse, funneling inward to a geometrical point of stillness; then the muted trombone again, and then, with a hushed crescendo, like a giant drawing breath, the final and colossal restatement of the melody (with one intriguing and as yet unsolved difference), which gathered pace and erupted into a wave, a racing tsunami of sound reaching an impossible velocity, then rearing up, higher, and when it seemed beyond human capability, higher yet, and at last toppling, breaking and crashing vertiginously down to shatter on the hard safe ground of the home key of $\mathrm{C}$ minor. What remained were the pedal notes promising resolution and peace in infinite space. Then a diminuendo spanning forty-five seconds, dissolving into four bars of scored silence. The end. (McEwan 1999: 42)

The processual character is expressed with the help of time adverbs and conjunctions (never, then, now, at last), dynamic verbs with the semantics of undulating deployment (climb, melt, spin away, funnel inward, erupt, race, rear up, break, crash and others), usage of gradation method.

However, the processual character of retellings is rather weak due to the discreet character of verbal messages. The impossibility of continual multi-level development in musical verbalizations leads to the outlining of only the most important moments, knots, and concentrations of sense. The author has to skip some parts, which leads to text compression and as a result, musical verbalizations are rather short and fragmentary.

Another criterion we applied in our research is the type of musical information rendered. We classify verbalizations into three types: verbalizations expressing the peculiarities of the musical sound substance, that is ones where the information on the elements of the plane of expression is dominant; verbalizations in which associative and figurative 
content is transmitted; and verbalizations in which the main attention is given to the transmission of the semantic content of the musical work.

Verbalizations of the first type belong to the sphere of imitative semantics. In the process of the sound substance transmission the lexical material is assimilated to the music. Material features of the substance matter of the verbal signs are used to more extent than it is typical for the verbal text. The peculiar rhythm organization of the text such as tonepainting, semantics of the sound symbolism, alliteration, assonance, onomatopoeia, intonation, timbre, sound intensity, and other imitative and dynamic and figurative potency of the sound matter allows to gain the stylistic similarity with different music effects. One of the examples of the masterly rhythm usage is found in Hoffmann's Kreislers musikalischpoetischer Klub, where the author gives characteristics to different music keys. While describing the E-flat major key Hoffmann uses short, abrupt, snappy phrases with multiple sound, lexical and syntactical repetitions, making the Kreisler's improvisation energetic and determinate.

Es dur (forte)

Zieh' ihm nach! - zieh' ihm nach! Grün ist sein Kleid wie der dunkle Wald - süßer Hornerklang sein sehnendes Wort! Hörst du es rauschen hinter den Büschen? Hörst du es tönen? - Hörnerton, voll Lust und Wehmut! - Er ist's - auf! Ihmentgegen! (Hoffmann 1958: 424)

Another example of imitative way of transmission of the music information can be found in Th. Mann's Doctor Faustus, where Professor Kretzschmar is talking about the Beethoven's 32 sonata. Metrical organization of the verbal material duplicates the rhythmic pattern of the arietta from the described music piece: “Dim-Dada, Himmelsblau, Leb' mir wohl, Wie-sengrund, Lie-beslied, Der-maleinst, O-du Himmelsblau, Grüner Wiesengrund, Leb - mir wohl, Nun ver-giß der Qual, Groß war - Gott in uns. Alles - war nur Traum, Bleib mir - hold ge-sinnt" (Mann 1975a: 76).

The substantial nature comes to the fore here, not the lexical meaning, the evidence of which can be seen in the usage of the empty word Dim-Dada, as well as repetition of lexical material in correlating expressions (Himmelsblau - $O$ du Himmelsblau; Wie-sengrund - Grüner Wiesengrund, etc.) imitating the peculiarities of music variations. Lexical meaning of the words arise indefinite associations which are united by the context though, so that they may be interpreted as the expression of the farewell theme.

The second type, that is transposition of associative and figurative content, is the most frequent and natural way of music verbalization, which render impressions from the music rather than the music content. 
As an example we shall cite the musical episode from Doctor Faustus, where the imitation of the music material is supported with metaphorical descriptions, causing tactile, kinetic and emotional reactions: "[...] dieses hinzukommendecisistdierührendste, tröstlichste, wehmutigversöhnlichste Handlung von der Welt. Es ist wie ein schmerzlich liebevolles Streichen über das Haar, über die Wange, ein stiller, tiefer Blick ins Auge zum letzten Mal" (Mann 1975a: 748).

It is typical for this type to use vivid synaesthesias, metaphorical comparisons, descriptions, which may evoke a particular emotional and aesthetic response, set the mood similar to the one people get from listening to the music itself. The advantage of the type consists in emotional sensitivity, expressiveness, as well as in the possibility to expose the images which allow to increase the verbalizations acquiring a relative processual and holistic character.

Another characteristic feature of this verbalization type is subjectivity of associations. The dominant role of visual information in comparison with the sound one in the person's life leads to the prevailing of visualspacial associations in musical verbalizations. Thus Irene's play in The Forsyte Saga is followed by Old Jolyon's impressions from Gluck's Orfeo.

'Would you like some Gluck?...'

'Ah! yes. Let's have 'Orfeo'. Round about him now were fields of gold and silver flowers, white forms swaying in the sunlight, bright birds flying to and fro. All was summer. Lingering waves of sweetness and regret flooded his soul. (Galsworthy 2001: 533)

The third type of verbalizations in our classification is presented by episodes where the music content is transmitted on the conceptual level. In this way the listener doesn't get the ready-made senses, but is let to experience them. The invariant content characteristic for all musical episodes like this is insight connected with supreme values and with the necessity to change the life.

The extract from Point Counter Point illustrates this type:

In the opening largo John Sebastian had, with the help of Pongileoni's snout and the air column, made a statement: There are grand things in the world, noble things; there are men born kingly; there are real conquerors, intrinsic lords of the earth. But of an earth that is, oh! complex and multitudinous, he had gone on to reflect in the fugal allegro. You seem to have found the truth; clear, definite, unmistakable, it is announced by the violins; you have it, you triumphantly hold it. But it slips out of your grasp to present itself in a new aspect among the 'cellos and yet again in terms of Pongileoni's vibrating air column [...]. 
It is a beauty, a goodness, a unity that no intellectual research can discover, that analysis dispels, but of whose reality the spirit is from time to time suddenly and overwhelmingly convinced. (Huxley 2004: 35)

Besides these three types of verbalization we can distinguish one more, which expresses not individual characteristics of particular music work, nor common music feelings, but rather special perception of attainment of truth, induced by music. Such verbalizations might be called meditative. In spite of some stylistic and world-view differences various authors have, all these verbalizations share some specific traits, such as: 1) attainment of high inner concentration and 2) impossibility to express this knowledge verbally to anybody else.

Here is an example from Kreutzer Sonata by Leo Tolstoy:

Music makes me forget my real situation. It transports me into a state which is not my own. Under the influence of music I really seem to feel what I do not feel, to understand what I do not understand, to have powers which I cannot have [...]. What was this new thing that I thus learned? That I did not realize, but the consciousness of this indefinite state filled me with joy. (Толстой 2013: 275)

In verbalizations of this type most distinctive is seen the reflective character of a music work contributing the attainment of altered state of consciousness and new ego level rather than just enlarging listener's thesaurus.

\section{Conclusion}

The study of musical verbalizations allows us to make some conclusions concerning the peculiarities of music and aestheticinformation transference into verbal form.

1. The complications in transmission of music information into verbal language are connected with such features of musical text as a low sign level, secondary character of denotations in reference to music signs, syntactic sign domination, continuity and multidimensionality of explication.

2. The relative correspondence of intersemiotic translation can be reached only on the level of the whole text or its inner form. The inner form here is understood as a compressed text, simultaneous image of the work, reflecting inner laws of the text structure and defining its sense and artistic integrity. 
3. The fact that music uses features of the sound material in more extent than fiction compels the writer to sacrifice some of the semantic meanings and concentrate more on some aspects, such as emotions, expressivity, figurative components, etc. In most cases several features on different levels are used.

4. We consider the most successful examples of musical verbalizations to be the ones which use verbal musical metalanguage, such as music terminology, where the main attention is paid to the description of syntactic structure explication, and at the same time emotional slant is expressed. Such peculiarities are characteristic of musical descriptions in the musicological literature - text books for musical institutions and of critical reviews. Such peculiarities are as well characteristic of musical verbalizations in fiction when it is important for the plot and the meaning of the work.

\section{References}

Adorno, Theodor (1969). Mahler. Frankfurt am Main: Suhrkamp Verlag.

Alshvang, Arnold (1964-1965). "Russkaya symphoniya i nekotoryie analogii s russkim romanom". (43-96). In: Izbrannyie soch. Vol. 1.

Aznacheeva, Elena (2006). "Intersemioticheskiye svyazi mezchdy literaturnokhudozchestvennym i muzikalnym tekstami". Russkaya germanistica 2: 234241.

Bobrovski, Viktor (1975). "Metody analyza muzykalnykh proizvedenii“. Voprosy teorii muziki 3: 3-9.

Boetius, Henning (1967). Utopie und Verwesung. Zur Struktur von Hans Henny Jahnns Roman "Fluß ohne Ufer". Bern: Lang.

Doderer, Heimito von (1966). "Sieben Variationen über ein Thema von Johann Peter Hebel". In: Unter schwarzen Sternen: Erzählungen. (213-238). München: Biederstein Verlag.

Dürr, Werner (1957). Hermann Hesse. Vom Wesen der Musik in der Dichtung. Stuttgart: Silberburg-Verlag.

Emrich, Wilhelm (1968). Das Problem der Form in Hans Henny Jahnns Dichtungen. Mainz: Akademie der Wissenschaft und der Literatur.

Feinberg, Samuil (1973). “Muzikalnaya struktura stikhotvoreniya Pushkina K Velmozche". Poeziya i muzika. 5: 281-320.

Fühmann, Franz (1980). Erzählungen 1955-1975. Rostock: VEB Hinstorff Verlag. Galsworthy, John (2001). The Forsyte Saga. Suffolk: Wordsworth Editions Limited. Gasparov, Boris (1973). "Nekotoryie aspekty semioticheskoi orientacii vtorichnyh modeliruyushchih system". In: Semiotyka i struktura tekstu. Studia poświęcone 
VII międzynarodowemu kongresowi slawistów. (33-44). Wrocław: Zakład Narodowy im. Ossolińskich.

Hesse, Hermann (1977). Der Kurgast. Frankfurt am Main: Suhrkamp Verlag.

Hildesheimer, Wald (1989). "Legende vom großen Bett". In: Deutschland erzählt. Von Rainer Maria Rilke bis Peter Handke. (146-159). Frankfurt am Main: Fischer Taschenbuch Verlag.

Hoffmann, Ernst (1958). "Kreislers musikalisch-poetischer Klub". In: Poetische Werke in sechs Bänden. Bd. I. (421-426). Berlin: Aufbau Verlag.

Huxley, Aldous (1960). "Preface". In: On Art and Artists. Ed. Morris Phillipson. (7-8). New York: Harper \& Bros.

Huxley, Aldous (2004). Point Counter Point. London: Vintage Classics.

Jacobson, Roman (1978). “O linguisticheskich aspektakh perevoda". In: Voprosi teorii perevoda v zarubezchnoi linguistike. (16-24). Moscow: Mezchdunarodnye otnosheniya.

Jung, Ute (1987). Die Musikphilosophie Thomas Manns: Kölner Beiträge zur Musikforschung. Regensburg: Gustav Bosse Verlag.

Langer, Susanne (1951). Philosophy in a New Key: A Study in the Symbolism of Reason, Rite and Art. New York: The New American Library.

Levi-Strauss [Леви-Стросс], Claude (1972). "Syroe i varyonoe". In: Semiotika i iskustvometriya. (25-49). Moscow: Mir.

Losev, Aleksei (1990). “Osnovnoy vopros philosophii muziki”. Sovetskaya muzika 11: 64-78.

Lotman, Yurii (1981). “Mozg - tekst - kultura - iskustvennii intellect". Semiotika i informatika 17: 3-17.

Mamleev, Yurii (1990). "Sleeping in the Forest". Znamya 7: 140-143.

Mann, Thomas (1974). "Buddenbrooks". In: Gesammelte Werke in 13 Bänden. Frankfurt am Main: Fischer.

Mann, Thomas (1975a). "Doktor Faustus". In: Romane und Erzählungen in 10 Bänden. Bd. 6. Berlin und Weimar: Aufbau-Verlag.

Mann, Thomas (1975b). "Tristan". In: Romane und Erzählungen in 10 Bänden. Bd. 9. Berlin und Weimar: Aufbau-Verlag.

McEwan, Ian (1999). Amsterdam. New York: Anchor Books Edition.

Orlov, Genrikh (1992). Drevo muziki. Saint-Peterburg: Sovetski kompozitor. Washington: H. A. Frager \& Co.

Petri, Horst (1964). Literatur und Musik: Form und Strukturparallelen. Göttingen: Sachse \& Pohl.

Tolstoy [Толстой], Leo (2013). Kreutzer Sonata. Repack by Diakov. Moscow: Astrel.

Upit, Andrei (1982). “Music”. In: Novels. (291-312). Moscow: Hudozhestvennaya literatura. 